\title{
BENCHMARKING CONCEPT OF SMALL SIZED CONSTRUCTION COMPANY
}

\author{
Dr Tomáš Hanák* \\ Faculty of Civil Engineering, Brno, Czech Republic \\ Dr Ivan Marović \\ Faculty of Civil Engineering, Rijeka, Croatia
}

Increasing competition on a global market forces enterprises to increase the efficiency of internal processes in order to retain competitiveness. Performance measurement is becoming one of the main strategic factors of business success, and can be performed also within the frame of benchmarking initiative. The aim of this paper is to draw up the benchmarking concept of small sized construction company, and verify its application on the case study. For this reason it was necessary to identify the set of performance indicators that can be measured and evaluated. It has been found out that firm size is limiting factor for application of benchmarking in the company, as well as unavailability of all necessary data. However, it was concluded that even a limited form of benchmarking provides a valuable information to the company management relevant to strategic decision making ensuring effective firm's management, and long term financial stability.

Key words: Benchmarking, Construction company, Cost, Financial ratio, Performance indicator

\section{INTRODUCTION}

Increasing competition on a global market forces enterprises to increase the efficiency of internal processes in order to retain competitiveness. This issue is even more important in construction industry suffering from the decrement of the volume of public and private tenders. Thus, it is necessary to focus on performance measurement which makes the establishment of feasible goals possible. The concept of measurement is strongly influenced by the industrial sector in which the company operates, and can be realized within the frame of benchmarking initiative. The aim of this paper is to draw up the benchmarking concept of small sized construction company, which will take into account encountered difficulties associated with the implementation of benchmarking, as well as future directions related to the potential creation of warning system. The applicability of the presented concept is subsequently validated on a case study based on one small sized construction company located in North-Moravian region of the Czech Republic.

The paper is structured as follows: Firstly, the literature review on the utilization of benchmarking in industry sector is introduced. Secondly, the re- search method used in this paper is presented. Thirdly, analysis and results are presented. Finally, discussion on applicability of benchmarking for small sized construction company is discussed together with the recommendations for company management, and possibilities of creating warning system.

\section{LITERATURE REVIEW}

Many research papers focus on the application of benchmarking in different industry sectors [03, $07,17,34]$, and thus a definition of term "benchmarking" is not unified.As benchmarking being defined as the art of learning from companies that perform certain tasks better than other companies [20], Išoraité [18] even argues that there is a considerable confusion as to what "benchmarking" actually means. Nevertheless, it is possible to identify the common essence among various definitions since benchmarking is widely understood as tool/process for improvement $[04,09,14,20,29,31]$. The improvement can be achieved if the institution measures its performance [26], furthermore many authors stress the element of "best practice" since they propose to measure processes against best-in-class companies $[01,18,21]$. 
The measurement of organizational or project performance is realized by means of performance indicators. Alarcón et al. [02] emphasize that the improvement of performance cannot be achieved by measurement alone. They argue the importance of analysis of these indicators with the objective to detect the problems and their causes. Just in this way the benchmarking may answer three basic question: "where are we now?", "where do we want to get?", and "how to get there?" [03, 29]. Having standard, systems and methodology of measurement is the necessary prerequisite in order to achieve required company's or project's efficiency [08, 14, 30].

If there is a willingness to apply benchmarking in the company, it is necessary to select appropriate benchmarking type to be used. Internal, competitive, parallel industry and best practice benchmarking types were introduced by [22] Internal benchmarking focuses on comparison between different divisions of a company, competitive benchmarking compares firms with similar products within same industry sector, parallel industry benchmarking considers between different sectors, and best practice draws a comparison to a market leader having exemplary process(es). It is obvious that firm size will be limiting factor for application of particular type of benchmarking in analysed company.

Since achieving "best practice" is not always a benchmark, authors consider than the most appropriate definition of benchmarking for the purpose of this paper is to be "Benchmarking enables an organization to identify its performance gaps and opportunities and develop continuous improvement programs for all stages of their process" [02].

Construction industry is specific in many ways. Firstly, its end product differs from other industries since construction products have long-term presence. Secondly, construction is a difficult process that has to be planned precisely including the planning of labour, machines, materials or equipment of construction site. Thirdly, building of the object is a long-term activity in comparison with e.g. food or steel industry. And finally, there are many different stakeholders involved in the process with their different needs and expectations during constructions life-cycle.

Above-mentioned facts clarify why performance measurement in construction is distinctive on the contrary to other industrial sectors. Performance indicators may be identified from company's or project's point of view $[02,10,12,25,28,30]$.Since this paper is focused on small sized construction companies, it is necessary to take into account also following facts: firstly, the main interest of construction companies to be involved in benchmarking is to compare their performance to other companies from the same market segment[10]; and secondly, small sized firms suffer from lack of resources [16]. Main difficulties are related especially to the lack of suitable partners, resource constraints and confidentiality of data [15].

\section{RESEARCH METHOD}

This paper investigates the application of benchmarking in small sized construction company. As seen in the literature review, there are 4 different types of benchmarking that might be used and there are also many different sets of performance indicators that can be measured.

Firstly, competitive benchmarking has been selected as the most appropriate for the purpose of this paper. Decision is based on following facts: Internal benchmarking is not applicable since small size construction company is too small and cannot be divided in divisions. Similarly, parallel industry benchmarking is not appropriate since construction sector is very specific and differs from other industry sectors. Best practice benchmarking approach is not relevant as well due to the large disproportion between "best practice" companies with high resources and constrained small sized companies.

Secondly, appropriate performance indicators were identified in available literature and discussed with the panel of experts with respect to the small sized character of the company.

Thirdly, it was necessary to check up if there are relevant data at disposal for the measurement of particular selected indicators.

Fourthly, one construction company has been appointed as the initiator of the project [33]. Consequently, several small sized construction companies were invited to join benchmarking initiative.Unfortunately, it has been encountered that it is very difficult to cope with the lack of suitable partners. There was not any comparable construction company from the same market segment willing to be involved in this benchmarking initiative. This constraint has been partially removed by using publicly available statistical data from Czech Statistical Office [11], Informa- 
tion System on Average Wage [24] and Benchmarking Diagnostic System of Financial Indicators INFA [23].

Finally, recommendations and improvements resulting from performed benchmarking initiative were formulated.

\section{PERFORMANCE INDICATORS AND AVAILABILITY OF DATA}

The subject of a case study is small sized construction company located in North-Moravian region of the Czech Republic. Portfolio of clients consists of both natural and legal persons (pri- vate i.e. business entity or public i.e. government organizations). The most common subjects of firm's activity are construction and reconstruction of family houses, and implementation of additional thermal insulation on buildings envelope. Company has 10 permanent employees, and for seasonal works firm hires additionalstaff.

Based on performed literature review, bellowmentioned performance indicators were selected as appropriate for benchmarking of small sized construction company. List of performance indicators including the information about availability of data can be seen in Table 1.

Table 1: Availability of data for selected performance indicators

\begin{tabular}{|c|c|c|c|c|c|}
\hline No. & Name & Formulae & Result & \multicolumn{2}{|c|}{ Availability of data } \\
\hline & & & & Firm & Market \\
\hline 01 & Cost Variation & $\begin{array}{l}\text { (Actual cost - budgeted cost) } \\
\text { / budgeted cost }\end{array}$ & Cost $[2,10,12,30]$ & $\mathrm{n} / \mathrm{a}$ & $\mathrm{n} / \mathrm{a}$ \\
\hline 02 & Schedule variation & $\begin{array}{l}\text { (Actual duration - planned } \\
\text { duration) / planned duration }\end{array}$ & Time $[2,10,30]$ & $\mathrm{n} / \mathrm{a}$ & $\mathrm{n} / \mathrm{a}$ \\
\hline 03 & Cost of client claims & $\begin{array}{l}\text { Cost of repairing claims / total } \\
\text { project costs }\end{array}$ & Quality [2, 30] & $\mathrm{n} / \mathrm{a}$ & $\mathrm{n} / \mathrm{a}$ \\
\hline 04 & Accident risk & $\begin{array}{l}\text { (No. of accidents * } 100 \%) \\
/ \text { total number of workers }\end{array}$ & Safety $[2,10,30]$ & $\mathrm{n} / \mathrm{a}$ & $\mathrm{n} / \mathrm{a}$ \\
\hline 05 & $\begin{array}{c}\text { Efficiency of direct } \\
\text { labour }\end{array}$ & $\begin{array}{c}\text { Planned man-hours / actual man } \\
\text { hours }\end{array}$ & Labour $[2,30]$ & $\mathrm{n} / \mathrm{a}$ & $\mathrm{n} / \mathrm{a}$ \\
\hline 06 & $\begin{array}{l}\text { Administration } \\
\text { productivity }\end{array}$ & $\begin{array}{c}\text { Cost of general } \\
\text { administration / monthly sales }\end{array}$ & $\begin{array}{c}\text { Company } \\
\text { management }\end{array}$ & ID & $\mathrm{n} / \mathrm{a}$ \\
\hline 07 & Market share & $\begin{array}{l}\text { Companies output / total } \\
\text { output in market segment }\end{array}$ & Market $[3,30]$ & ID & $\mathrm{n} / \mathrm{a}$ \\
\hline 08 & Return on equity & Net income / shareholder equity & Profitability $[12,23,30]$ & ID & [23] \\
\hline 09 & Net profit margin & $($ Net profit * 100\%) / revenue & Profitability [12, 23, 30] & ID & [23] \\
\hline 10 & Asset turnover & $\begin{array}{c}\text { Net sales revenue / total } \\
\text { assets }\end{array}$ & Turnover [23] & ID & {$[23]$} \\
\hline 11 & Equity ratio & $\begin{array}{l}\text { Total shareholder's } \\
\text { equity / total assets }\end{array}$ & Capital structure ${ }^{[23]}$ & ID & [23] \\
\hline 12 & Cash ratio & $\begin{array}{c}\text { (current assets - inventory - ac- } \\
\text { counts receivable) } \\
\text { / current liabilities }\end{array}$ & Liquidity [23] & ID & {$[23]$} \\
\hline 13 & Current ratio & $\begin{array}{c}\text { Current assets / current } \\
\text { liabilities }\end{array}$ & Liquidity [23] & ID & {$[23]$} \\
\hline 14 & $\begin{array}{l}\text { Average month } \\
\text { salary of worker }\end{array}$ & $\begin{array}{c}\text { Sum of annual salaries of workers } \\
\text { / (no. of worker * 12) }\end{array}$ & Labour [24] & ID & {$[24]$} \\
\hline 15 & $\begin{array}{l}\text { Average month } \\
\text { salary of technician }\end{array}$ & $\begin{array}{c}\text { Sum of annual salaries of } \\
\text { technicians / (no. of } \\
\text { technicians * 12) }\end{array}$ & Labour [24] & ID & {$[24]$} \\
\hline 16 & $\begin{array}{l}\text { Costs for labour as } \\
\% \text { of revenue }\end{array}$ & $\begin{array}{l}\text { Total costs for } \\
\text { labour / revenues }\end{array}$ & Labour [33] & ID & {$[11]$} \\
\hline 17 & $\begin{array}{l}\text { Inventory as \% } \\
\text { of Revenue }\end{array}$ & Value of inventory / revenues & Inventory [33] & ID & {$[11]$} \\
\hline 18 & $\begin{array}{l}\text { Material as \% } \\
\text { of revenue }\end{array}$ & $\begin{array}{c}\text { Total costs for } \\
\text { material / revenues }\end{array}$ & Material oc & ID & $\mathrm{n} / \mathrm{a}$ \\
\hline
\end{tabular}

Note: ID = internal data of examined company, OC = own construction. 
The adequacy of indicators was considered especially in relation to the ability and effectiveness to record specific data in a detailed level. Data necessary for evaluation of proposed performance indicators may be obtained from different sources. At subject company level, data recording is partly obligatory, e.g. in the form of balance sheet or profit and loss account. Other important indicators require detailed voluntary evidence in the form of management accounting providing crucial information for proper company's management. Therefore, management accounting is considered to be primary data source for the purpose of this study. On the other, in particular cases it can be beneficial to use publicly available data, processed and published by statistical offices, authorities or relevant professional associations or chambers. The availability of needed data is given in the last two columns of Table 1.

Proposed list of indicators is aimed to monitor key company's processes which are presented in following paragraph.Based on observations, most common problems related with building orders are those related with time, costs and quality. As the value of planned and actual costs for construction contracts often vary (e.g. due to extra works, changes in the prices of materials, etc.), it is advisable to monitor cost variation (indicator no. 1 ; 11). Similar differences also arise for schedule; schedule variation is therefore a logical parameter suitable for observation (I2). With regard to the evaluation of the quality of the work performed, it seems to be interesting to observe cost of client claims (as a share of costs of repairing claims on total project costs, I3). Because it is desirable to reduce the number of accidents on construction site, it is necessary to monitor achieved level of safety with respect to the riskiness of execution of construction works by means of indicator no. 5. Administrative costs may significantly affect the company's competitiveness, thus observation of this aspect is ensured by means of administration productivity indicator (I6). Increasing market share is one of the most important objectives of business. This indicator (I7) partially eliminates the influence of macroeconomic variables such as GDP growth and therefore activities carried out within the frame of marketing analysis should be also directed to this area.

Group of indicators 18 - 113 serves to evaluate the financial health of the company from different perspectives such as prosperity, liquidity, turnover or capital structure. Correct setting of wage tariffs for key professions in the company is monitored by indicators no. 14 and 15 . Furthermore, because building production is manpower-intensive, it is worth to compare the total labor costs and revenues as well (I16). Another costly activity in building industry is storage, thus the relative value of inventory is a parameter of great importance (I17). And finally, if we want to prevent e.g. wasting of materials, it is essential to observe materials management system e.g. by means of the portion of material costs on total revenues (I18).

\section{DISCUSSION}

It was found that without suitable partners willing to participate in benchmarking initiative it is not possible to completely collect all necessary data for all selected performance indicators, especialIy those related with cost, time, quality, safety, company management, and material. This fact significantly reduces the value of benchmarking outputs for construction company, because for its proper operation it is crucial to record:

- budgeted and real costs of construction orders (consequence: reduced profit or even loss);

- actual and planned duration of construction (consequence: contractual penalty);

- data on safety at work (consequence: enhanced costs for indemnification, and for construction all risk (CAR) insurance or erection all risk (EAR) insurance); and

- client claims (consequence: labour and/or technological weaknesses are not discovered).

Cost analysis is a subject of particular interest, no matter if it is about costs for materials (usually forming about $60 \%$ of total costs of construction) or machines. Information on costs in management accounting of the company should be detailed, allowing in-depth analysis of e.g. costs of machines for transport, operation, fuels or depreciation [27], oranalysis of relation between contracted price and time overrun[36]. Such data are not covered by statistical services. Unfortunately, data on indicators no. $1-5$ were not recorder neither by examined construction company.

On the other hand, limited form of benchmarking can be applied to other performance indicators related especially to financial ratios allowing evaluation of "financial health" of a subject. 
Required data on the level of the firm has to be stated in balance sheet as well as in profit and loss account. This case study employees 9 financial ratios; if the purpose of assessment is solely financial health of the firm, a larger set of financial ratios might be used. For that purpose authors in [32] suggested 17 ratios whileanother research [35] suggested16 ratios. Average financial data on similar companies operating on the market can be collected from various databases and statistical services, however the availability and details may vary from country to country. Nevertheless, above-mentioned available outputs are not enough to investigate all crucial processes within the company.

For the evaluation of indicator no. 7 it is not necessary to have at disposal data from the market, however it might be very interesting to observe the market share of comparable competitors. Notwithstanding, from the long term perspective the indicator itself expresses whether the company rises or not. In this case, the market is geographically limited to the region of South Moravia and Silesia since the company carries out its activities only in this territory.

Next financial ratios provide relevant information to the rate of return on the equity (no. 08), profitability of the company by means of net profit as a percentage of the revenue (no. 09), how efficiently the company is utilizing its assets to produce revenue (no. 10), and to relative proportion of equity applied to finance the assets of a company (no. 11).

Liquidity is one of the factors sensitive to the economic changes in the country. EminÖcal et al. [13] have proved that continuous analysis of this factor together with capital structure and profitability, activity efficiency, profit margin and growth, as well as assets structure would provide sufficient information related with both the relative state of the industry with respect to time, and the relative state of any construction company with respect to their rivals. Cash ratio (no. 12) is usually used as a measure of company liquidity in the form of most liquid short-term assets usually used to pay off current obligations. The second liquidity indicator, current ratio (no. 13), describes the ability to meet short-term liabilities by means of company's short-term assets. If the liquidity is considered as an important factor, the third measurement ratio, cash ratio, can be easily added.

Comparison of wage indicators (no. 14, 15 and 16) has to be based only on the South Moravian and Silesian region due to the fact that wages in different regions of Czech Republic are considerably different. It is of particular interest to analyse wages according to professions in order to avoid misrepresentation of the results caused by different employment structure; which can be especially important for small companies.

Proper material management is of strategic interest due to the large proportion of material costs on total costs as well as inventory management, because storage is expensive activity involving costs for warehouse operations, its management, guarding or insurance.

Various measures can be taken in order to improve company's assessment. Positive effect can be achievede.g. by implementation of safety management programmes, especially if speaking about construction sector. Authors in [05] have reported improvements in project ROI (return on investment) as a benefit of such programmes. Differences in safety climate perception are considerable between firms; study of Blazhevska et al. has discovered such differences even regarding employee's work position, age and tenure [06]. Therefore, employers must take appropriate activities to provide safe and healthy work conditions and insurance coverage to avoid expenses related with indemnity (to learn more see [19]).

Performed case study analysis has detected unsatisfactory data record management on the level of examined company. Thus, it is recommended to start recording data necessary for future evaluation of performance indicators no. 1-5. Later on, when suitable partners will be available to participate in benchmarking initiative, the data for comparison will be at disposal already. It should be noted that, for the correct interpretation of the indicators is essential to carry out the assessment in the long term run. The actual values of just one year are not sufficient, because it is crucial to identify trends of company development. Even though the recorded specific annual value of the indicator is appropriate, in the long term perspective it should indicate a negative development in comparison with previous periods. Therefore, it is recommended to take into account the period of last 5 years, if applicable. The whole benchmarking concept is graphically demonstrated in Figure 1. The concept takes into account encountered difficulties associated with the implementation of benchmarking as well as future directions related to the potential creation of warning system. 


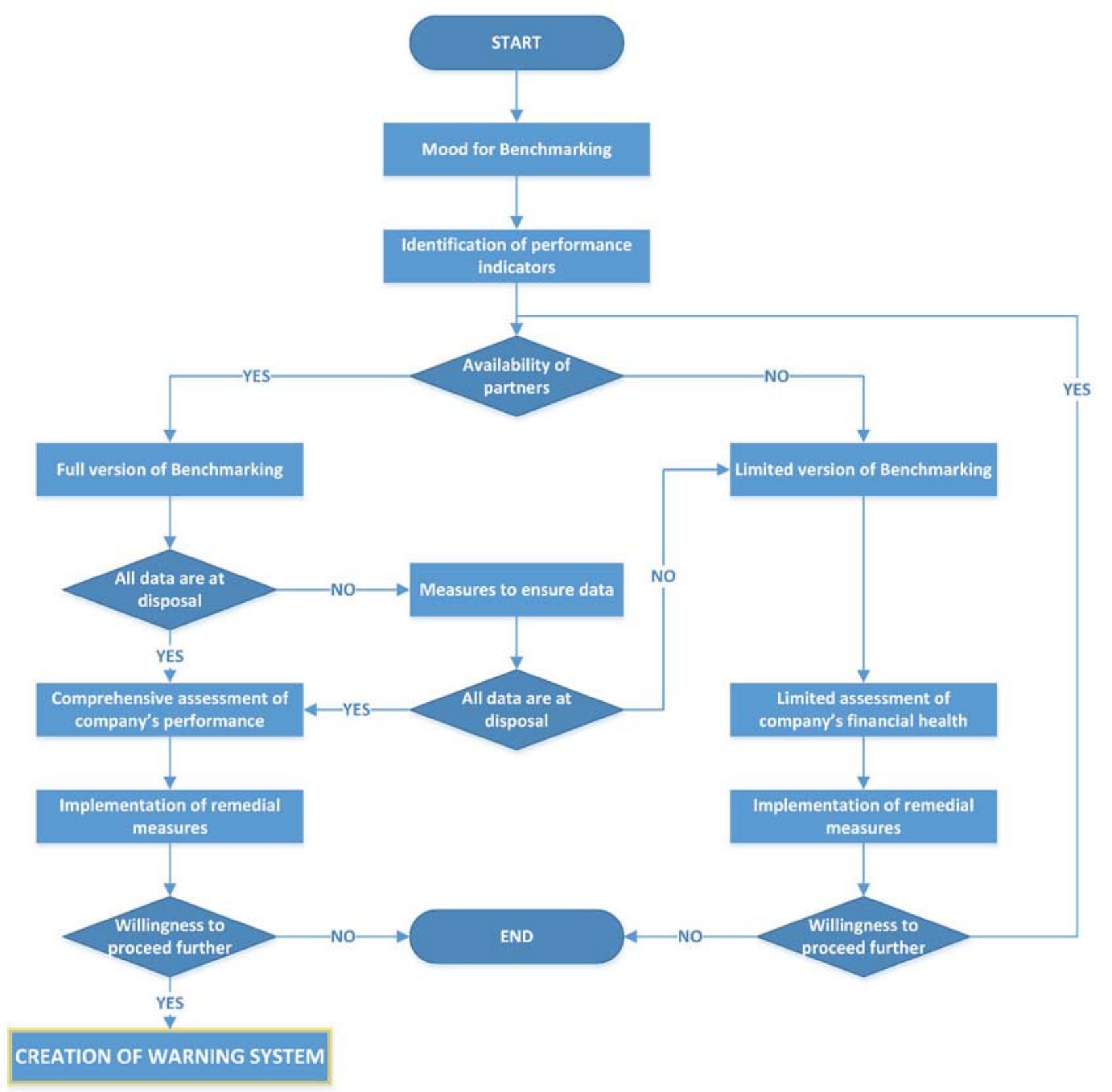

Figure 1: Scheme of benchmarking concept

This study has confirmed findings on benchmarking reported by other studies. Above all, the crucial issue is to cope with the lack of resources [16], the lack of suitable partners and confidentiality of data [15]. It has to be pointed out, that the performance of above mentioned recommendations can require an employment of a new worker resulting in the increment of labour costs and significantly affecting the values of closely related examined indicators (no. 06, 09 and 16). Hereafter, the benefits of benchmarking outputs must be clearly explained in order to strongly motivate suitable partners to join the benchmarking initiative, and to share internal data with others.

\section{CONCLUSION}

Benchmarking is one of the suitable approaches allowing to measure performance of the company. The application of the proposed concept would allow identification of the key processes with significant impact on the company performance and introduction of better practices related to these processes. However, the possibilities of benchmarking application are largely dependent on the limiting factors such as the availability of data and size of the company. Despite all the obstacles, even a limited form of benchmarking provides to company management valuable information relevant to strategic 
decision making and supports ensuring effective firm's management,as well as long term financial stability. Yet it should be noted that the limited version is particularly useful for evaluating the financial health of the company, while the essence of a comprehensive assessment of the competitiveness of the company cannot be fulfilled in this way.

A case study has shown that the critical issue is to find partners willing to participate in benchmarking initiative and therefore have at disposal corporate data allowing comparison of internal processes between companies. It should be noted that the indicators must be evaluated annually from the long term perspective. In such case it is possible to monitor trends and take appropriate remedial measures in a timely manner. Introduced concept of benchmarking is completely feasible only if there are more comparable companies willing to participate in the initiative.

Future research should be also directed towards the development of a warning system allowing timely indication of the occurrence of adverse phenomenon such as lack of liquidity, material waste or low labour utilization. For this purpose, detailed data collection is necessary optimally in monthly interval.

\section{REFERENCES}

1) Acord, T.,(2000)Defining benchmarking,FDM: Des Plaines, 72 (15), 34-35.

2) Alarcón, L.F., Grillo, A., Freire, J., Diethelm, S., (2001) Learning from collaborative benchmarking in the construction industry,IGLC-9, Proceeding of the Ninth International Group for Lean Construction Conference.Available at: http://cic.vtt.fi/lean/singapore/Alarconet.pdf

3) Antošová, M., Csikósová, A., Čulková, K., Seňová, A., (2013) Benchmarking research of steel companies in Europe,Metalurgija, 52 (3), 410-412.

4) Bednárová, L., Liberko, I., Weiss, R., (2009) Benchmarking $\mathrm{v}$ riadenipodnikov, In: ActaMontanisticaSlovaca, 14 (1), 86-91.

5) Bernstein, H.M., Russo, M.A., (2013) Contractor safety programs yield financial benefits,ENR (Engineering News-Record), 271 (7). (accepted for publication)

6) BlazhevskaStoilkovska, B., ZileskaPancovska, V., Mijoski, G., (2013) Perceptions of Work Safety among Employees in Construc- tion Sector in Macedonia, In Proceedings of International Conference Safety Engineering in Function of Improvement of the Working Conditions, Ohrid, pp. 249-255.

7) Borgia, C., García-Bolaños, M., Li, T., GómezMacpherson, H., Comas, J., Connor, D., Mateos, L., (2013) Benchmarking for performance assessment of small and large irrigation schemes along the Senegal Valley in Mauritania, Agricultural Water Management, 121, 19-26.

8) Ćetković, J., Knežević, M., Ivanišević, N., Rutešić, S., (2010) Mark of the investment projects in civil engineering with the special retrospection to the economical-financial mark of the project, Terra Spectra - Central European Journal of Spatial and Landscape Planning, 2 (1), 47-55.

9) Clark, A.M., Atkin, B.L., Betts, M.P., Smith, D.A., (1999) Benchmarking the use of IT to support supplier management in construction, Journal of Information Technology in Construction, 4 (1-16), Available from: http:// www.itcon.org/1999/1

10) Costa, B. D., Formoso, C. T., Kagioglou, M., Alarcon, L. F., (2004) Performance Measurement System for Benchmarking in the Construction Industry, Proc. 12th IGLC Conf. LOSchool, Elsinore Denmark, 451-463.

11) Czech Statistical Office, official web page. Available from: http://www.czso.cz/

12) Egan, J., (1998) Rethinking construction: report of the construction task force on the scope for improving the quality and efficiency of UK construction. HMSO. Available from: http://www.constructingexcellence.org.uk/ pdf/rethinking\%20construction/rethinking_ construction_report.pdf

13) EminÖcal, M., Oral, E.L., Erdis, E., Vural, G., (2007) Industry financial ratios-application of factor analysis in Turkish construction industry,Building and Environment, 42 (1), 385-392.

14) Harrington, H.J., Harrington, J.S., (1996) High Performance Benchmarking: 20 steps to success, McGraw-Hill, USA.

15) Holloway, J.A., Hinton, C.M., Mayle, D.T., Francis, G.A.J., (1997) Why benchmark? Understanding the processes of best practice benchmarking, Proceedings of Business, Track, British Academy of Management Conference, London, 271-291. 
16) Hudson, M., Smart, A., Bourne, M., (2001) Theory and practice in SME performance measurement systems. International Journal of Operations and Production Management, 21(8), 1096-1115.

17) Hung, C.-T., (2013) Evaluating and benchmarking productive performance of shipping companies,Applied Mechanics and Materials, 284-287, 3675-3678.

18) Išoraite, M.,(2004) Benchmarking methodology in a transport sector, Transport, 19 (6), 269-275.

19) Klasić, K., Janzetić, M., (2010) Insurance of individuals on construction sites,Sigurnost, 52(1), 35-47.

20) Kotler, P., (1994) Marketing management - Analysis, Planning, Implementation and Control, Prentice Hall, New Jersey.

21) Leibfried, K.H.J., McNair, C.J., (1994) Benchmarking: a tool for continuous improvement, HarperCollins Publishers, London.

22) Lewis, J.C., Naim, M.M., (1995) Benchmarking of aftermarket supply chains, Production Planning and Control, 6 (3), 258-269.

23) Ministry of Industry and Trade of the Czech Republic. Benchmarkingovýdiagnostickýs ystémfinančníchindikátorů INFA. Available from: http://www.mpo.cz/cz/infa.html

24) Ministry of Labour and Social Affairs of the Czech Republic. Informačnísystém o průměrnémvýdělku. Available from: http:// www.mpsv.cz/clanek.php?lg=1\&id=1928

25) Mbugua, L.M., Harris, P., Holt, G.D., Olomolaiye, P.O., (1999) A framework for determining critical success factors influencing construction business performance, In: Hughes, W. (ed) Procs. 15Th Annual ARCOM Conference. September 5-7, Reading: ARCOM. 1, 255-264.

26) Morling, P., Tanner, S., (2000) Benchmarking a public service business management system,Total Quality Management, 11 (4-6), 417-426.

27) Petronijevič, P., Ivaniševič, N., Rakočevič, M. Arizanovič, D., (2012) Methods of calculating depreciation expenses of construction machinery,Journal of Applied Engineering Science, 10(1), 43-48.
28) Pillai, A. S., Joshi, A., Rao, K.S., (2002) Performance measurement of R\&D projects in a multiproject, concurrent engineering envir onment, International Journal of Project Management, 20, 165-177.

29) Renko, N., Delić, S.,Škrtić, M., (1999) Benchnmarking u strategijimarketinga, Mate, Zagreb.

30) Takim, R., Akintoye, A., (2002) Performance indicators for successful construction project performance, In: Greenwood, D (Ed.), 18th Annual ARCOM Conference, 2-4 September 2002, University of Northumbria. Association of Researchers in Construction Management, Vol. 2, 545-55.

31) Van Schalkwyk, P.W., Smith, E., Morgan, N.,(1996) Contemporary Issues in Strategic Management,Kagisco Publishers, Pretoria.

32) Varghese, B., Menacere, K., (2012)The financial health of construction companies in Qatar: A case study,International Journal of Engineering Research in Africa, 8, 55-72.

33) Waszek, J., (2013) Optimalizacenákladůves tavebnímpodniku, Final thesis, Brno University of Technology, Faculty of Civil Engineering. 105 p. Mentor

34) Yakovleva, N., Sarkis, J., Sloan, T., (2012) Sustainable benchmarking of supply chains: The case of the food industry, International Journal of Production Research, 50 (5), 1297-1317

35) Yunus, N.M., Malik, S.A., (2012) Development of financial model using financial ratios in predicting business performance of IBS construction company, ICSSBE 2012 - Proceedings, 2012 International Conference on Statistics in Science, Business and Engineering: "Empowering Decision Making with Statistical Sciences" 2012, 209-214.

36) Žujo, V., Car-Pušić, D., Brkan-Vejzović, A., (2010) Contracted price overrun as contracted construction time overrun function, Tehnic kiVjesnik, 17(1), 23-29.

Paper sent to revision: 13.11.2013.

Paper ready for publication: 11.12.2013. 